\title{
Comparative analysis of the amino acid sequence of the Cry protein of Bacillus thuringiensis codify the toxic protein to insects of the orders Lepidoptera, Diptera and Lepidoptera/ Diptera
}

\author{
Hagar Maciel ${ }^{1 *}$, Sonia Zingaretti ${ }^{2^{*}}$, Geveraldo Maciel $^{1 *}$ \\ From 5th Congress of the Brazilian Biotechnology Society (SBBIOTEC) \\ Florianópolis, Brazil. 10-14 November 2013
}

\section{Background}

The use of $B t$ crystal protein as a natural insecticide, applied directly to crops has been true for many years. Cry genes codifing these proteins are already are being used in transformation plants that become resistant to certain insects. The aim of this study was to compare the amino acid sequences that encode the Cry protein to insects of the orders Lepidoptera, Diptera and Lepidoptera / Diptera. We evaluated 15 sequences that were deposited in the GenBank and using bioinformatics tools to align and compare these sequences that present three domains (I, II, and III). It is assumed that changes in these domain influence the toxicity of the protein and her order. The results presented indicate the presence of specific regions and that may be related to the specificity of protein toxicity.

\section{Methods}

The search and download all the amino acid sequences by domains: I, II and III, of the GenBank and of the program to consult "The Blast" - "Basic Local Alignment Search Tools (Altschul et al., 1997).

The sequences were divided into the following insect orders: Coleoptera, Diptera, Lepidoptera, Lepidoptera and Coleoptera, Lepidoptera and Diptera and Heminóptera.

To compare the sequences based on similarities between the genes that act on a particular species we selected 5 genes described that attack insects of the order Lepidoptera: Cry1Ba1, Cry1Ba2, Cry1Bb1, Cry1Ca1,

\footnotetext{
'Instituto Federal de Educação, Ciência e Tecnologia do Sul de Minas Campus Machado, Carvalhópolis, Brazil

${ }^{2}$ Universidade de Ribeirão Preto - Unaerp, Ribeirão Preto, Brazil

Full list of author information is available at the end of the article
}

Cry1Ca2; 5 genes of the order Diptera: Cry4Ba1, Cry4Ba2, Cry10Aa1, Cry16Aa1, Cry19Ba1 and 5 genes, whose toxin attacks insects of the order Lepidoptera and Diptera: Cry1Aa1, Cry1Aa2, Cry1Ab1, Cry1Ab2, Cry1Ac1 and by to align these sequences using the software CLUSTAW v.1.81 (Thompson et al., 1997).

\section{Results and conclusions}

This analysis revealed the occurrence of identical sequences in the 3 domains, $\mathrm{I}=16, \mathrm{II}=\mathrm{III}=6$ and 14 positions. Most of these amino acids belong to the group $\mathrm{R}$ nonpolar and aliphatic amino acids and not were occur amino acids positively charged $\mathrm{R}$ group in Domain $\mathrm{I}$.

In the domains I, II and III was found that 8, 5 and 7 positions, respectively, were changes between amino acids of the same group (preserved), representing 40, 25 and $35 \%$.

In the field I was exchanging groups of amino acids conferring differences in behavior and stability of the molecule. The exchange of amino acids at positions 192, 226 and 171 provided a more hydrophilic molecule while the exchanges of amino acids at positions 142, 49 and 87 provided a more hydrophobic molecule.

Position 224 in domain II, and domain III at position 84 was exchanged amino acids increasing the stability of proteins by promoting hydrophobic interactions in the your interior.

When has been change in the amino acid change from one group to another modifying the chemical structure of the protein, their polarity and consequently their solubility in water and its interactions with other amino acids. 


\section{Authors' details}

'Instituto Federal de Educação, Ciência e Tecnologia do Sul de Minas -

Campus Machado, Carvalhópolis, Brazil. ${ }^{2}$ Universidade de Ribeirão Preto -

Unaerp, Ribeirão Preto, Brazil.

Published: 1 October 2014

\section{References}

1. Crickmore N, Zeigler DR, Schnepf E, Van Rie J, Lereclus D, Baum J, Bravo A,

Dean DH: Bacillus thuringiensis toxin nomenclature. 2005 [http://www.

lifesci.sussex.ac.uk/Home/Neil_Crickmore/Bt].

2. Crickmore $N$, et al: Revision of the nomenclature for the Bacillus

thuringiensis pesticidal crystal protein. Microbiology and Molecular Biology Reviews 62, 3:807-813.

3. De Maagd RA, DE, et al: Structure, diversity and evolution of protein toxins from sporeforming entomopathogenic bacteria. Annual Review of Genetics 2003, 37:409-433.

4. Hofte $H$, et al: Monoclonal antibody analysis and insecticidal spectrum of three types of lepidopteran-specific insecticidal cristal proteins of Bacillus thuringiensis. In Applied Environmental Microbiology. Volume 54. Washington; 1988:(8):2.010-2.017.

5. Lereclus D, et al: Regulation of toxin virulence gene transcription in Bacillus thuringiensis. Int Journal Medical Microbiology 2000, 290:295-299.

doi:10.1186/1753-6561-8-S4-P120

Cite this article as: Maciel et al:: Comparative analysis of the amino acid sequence of the Cry protein of Bacillus thuringiensis codify the toxic protein to insects of the orders Lepidoptera, Diptera and Lepidoptera/ Diptera. BMC Proceedings 2014 8(Suppl 4):P120.

\section{Submit your next manuscript to BioMed Central} and take full advantage of:

- Convenient online submission

- Thorough peer review

- No space constraints or color figure charges

- Immediate publication on acceptance

- Inclusion in PubMed, CAS, Scopus and Google Scholar

- Research which is freely available for redistribution

Submit your manuscript at www.biomedcentral.com/submit 